\title{
下斜筋過動を有する患者の術前・術後の
}

\section{視力、両眼視、その他についての考 察}

近江眼科 川口薫 - 藤田 純子

\section{I 緒 言}

斜視に下斜筋過動を合併することは, しばし ば見られる。下斜筋過動を有する斜視の手術方 法, 手術の定量, その他についての詳しい研究 は比較的少なく，最近の報告では，高久氏らに よる45例の報告がある。我々は昭和 44 年 4 月よ り 47年 7 月までの約三年間に，全身麻酔下で手 術を施行した65㱐例 104眼について，経過を観 察したので報告する。

$$
\text { II方 法 }
$$

患者の平均年令は 4.5 才。屈折度はミドリン およびアトロピン散瞳による合致式レフラクト メーターの屈折度による完全矯正を行ない, 全 身麻酔下で下斜筋切除後転法を施行した。術

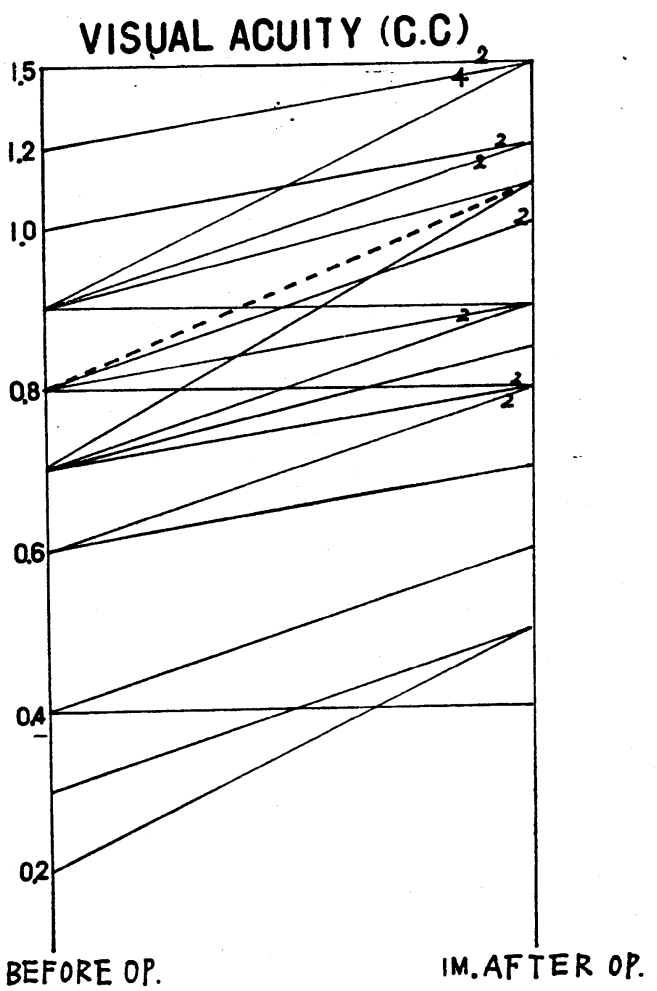

図 1
前, 術後を通じて同一の矯正眼鏡を用い, 術前 と術後約 1 カ月間のシノプトフォアを中心とし た視能訓練後に視力, シノプトフォア prismcover-test, Hess-Chart test, EOG, 角膜曲 率半径などにつき測定を行ない, 術前, 術後の ものを，比較検討した。

\section{III 結 果}

視力の変化は図 1 亿示した。矯正平均視力は

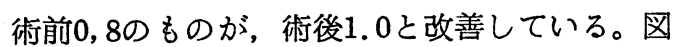
2 は術前術後の両眼視機能の比較で Grade I. II. Fusion は術後改善している。水平斜視角 を合併した例について prism-cover-test によ る $1 / 3 \mathrm{~m}$ の水平斜視角の変化をみると, 術前を 0 ，術後を 100 とすると，減少率は $38 \%$ となっ

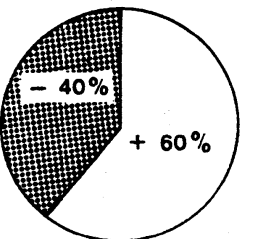

GRADE I FUSION (SP)
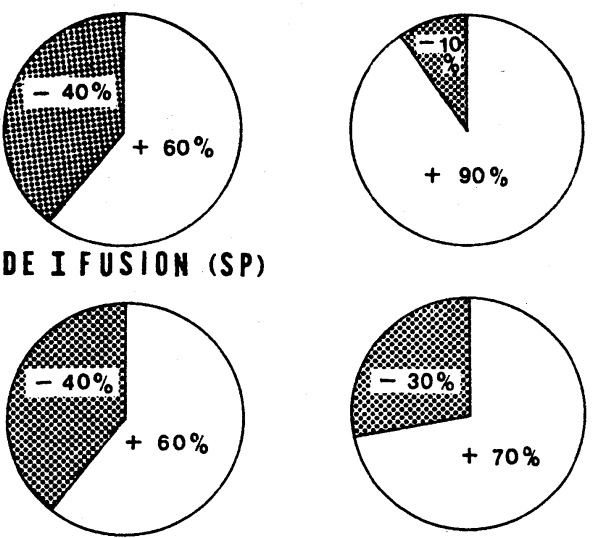

GRADE II FUSION
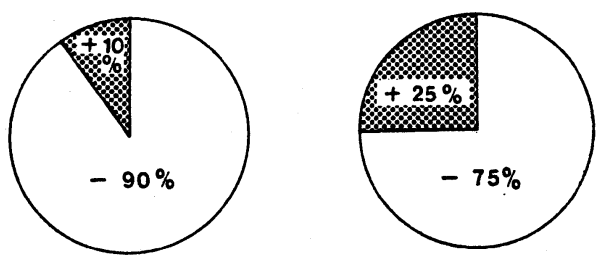

GRADE II FUSION

BEFORE OP.

AFTER OP.

図 2 術前・術後の両眼視機能の比較 
た。術前, 術後の Hess-Chart-test の結果を

みると，術後全体的に改善されている。

N．結論わよび考察

下斜筋過動を有する斜視眼に対して，下斜筋 切除後転を行ない, 視力, 両眼視機能などにつ き検討を行なった結果，良好な結果を得た。

このことは下斜筋術後に下斜筋過動が消失す るためおそらく異常な回旋がなくなり垂直斜 視が消え，融像域が大きくなるためと思われ
る。

Grade I. I . Fusion は術後改善され, Grade I. Fusion は術後の視能訓練が重要であり, 下斜筋過動症について, 視力の改善, 両眼視機 能を獲得するためには，下斜筋過動の早期手術 が必要であるとの結論を得た。下斜筋過動がど のような経過をたどるか, さらに長期にわた り, 視力, 両眼視, 眼位を平行して経過観察し ていきたいと考えている。
金眼 原科 出学 版書 の選

\section{幼 \\ 年 \\ 弱

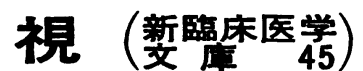 \\ 弓削経一 著 \\ B 6 判 198頁 63 図 $¥ 1,300$

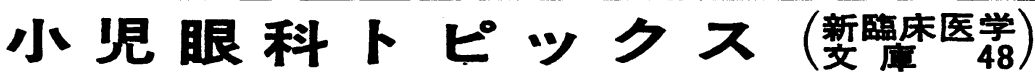
植村恭夫 湖崎 克 共著 B 6 判 254 頁 102 図 $¥ 1,500$ 余斗 視の 診 断と治痊 (㜪臨床医学) 丸尾敏夫 久保田伸枝 共著古6 判 180 頁 82 図 $¥ 1,500$

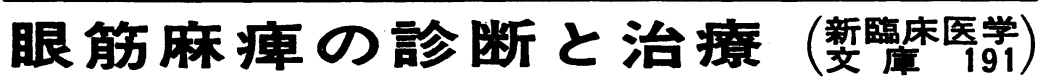
丸尾敏夫 久保田伸枝 共著等 B 6 判 204頁 113 図 $¥ 1,500$ 弱 視 の 診 断と治療

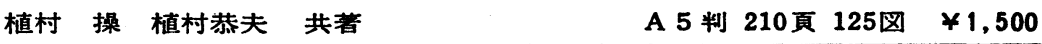
コンタクトレンズ処方と苦情処理 湖崎 克 編 A 5 判 144 頁 91 目 $¥ 2,300$ 眼 底 撮 影豈 実 際 三国政吉 八百枝 浩 共著

A 5 判 152 頁 149 因 $\quad ¥ 3,600$

図害目録呈

原 U113-91 東京都文京区湯島 2-31-14 金原出版株式会社 Tel 東京(03)811-7161／振替果京151494 